https://doi.org/10.48009/2_iis_2006_171-176

\title{
STATE E-GOVERNMENT SERVICE AND ECONOMIC COMPETITIVENESS: A RELATIONAL ANALYSIS
}

\author{
Dr. Jensen J. Zhao, Ball State University, jzhao@bsu.edu \\ Dr. Allen D. Truell, Ball State University, atruell@bsu.edu \\ Dr. Melody W. Alexander, Ball State University, malexand@bsu.edu \\ Dr. Rod Davis, Ball State University, rdavis2@bsu.edu
}

\begin{abstract}
This study examined the characteristics and capabilities of the e-government service sites of the 50 U.S. states and Washington, D.C. and their relationships with the economic competitiveness.
\end{abstract}

Keywords: E-government Service, E-government Characteristics, E-government Capabilities, Egovernment Economic Competitiveness

\section{INTRODUCTION}

E-government generally refers to the delivery of government services on the Internet for serving the constituents more effectively and efficiently. Strategically, e-government is also viewed as a key factor for leveraging economic competitiveness. For instance, while the European Commission considered e-government as a key element of Europe's competitiveness agenda [4], the U.S. federal government committed to expand e-government for being the best [5]. The use of information and communication technology is widely seen as the main factor for explaining the growing productivity gap between the European Union and the United States over the last decade, leading to an even wider gap in GDP growth, employment levels, and living standards [4], although no empirical data were found to support such viewpoint.

To identify the connection between e-government service and economic competitiveness, Wilkinson and Cappel [11] studied the relationship between economic prosperity and e-government involvement at the county level in Michigan and found that the median personal income and population size correlated significantly with the county e-government involvement. However, no similar empirical studies at the federal or state level have been identified in the literature. This research gap suggests a need for further research.

This study investigates the relationship between the state e-government service and economy competitiveness. To conduct the investigation, we raised the following research questions:

What are the characteristics of the e-government service sites of the 50 U.S. states and D.C.?

What are the capabilities of the e-government service sites of the 50 U.S. states and D.C.?

How do the state e-government service capabilities correlate with the state per capita personal income and higher education attainment?

\section{METHODOLOGY}

Content analysis is commonly used in assessing organizations' Web contents, deliveries, and strategies [e.g., 2, 11, 13]. This method is ideal for making inferences by systematically and objectively recording the characteristics and capabilities of state e-government service sites and identifying whether a significant relationship exists between state egovernment capabilities and economic competitiveness.

The population of this study was the official government Web sites of the 50 U.S. states and Washington, D.C. These 51 sites were all used in the study according to the sample-size requirement [3]. We developed an instrument based on the related literature for (a) recording the characteristics of state e-government sites, (b) measuring the capabilities of the sites, and (c) identifying whether the state economic competitiveness correlates significantly with the state e-government capabilities.

The e-government capabilities were measured in terms of Web page loading speed, site capacity, navigation convenience, and overall attractiveness to users on a four-point Likert scale based on the literature [e.g., 1, 6, 7, 8, 11, 12, 13]. For example, the page loading speed was rated on the broadbandconnected PCs with (1) more than four seconds = not efficient, (2) three to four seconds = less efficient, (3) one to two seconds = efficient, and (4) less than one second $=$ very efficient [e.g., 1, 13] . 
The site capacity was ranked with four evolutional phases: (1) informational $=$ allowing users to get information only; (2) interactive = enabling users to get or search for information, download forms, and send email; (3) transactional = allowing users to do business online such as filing tax documents, renewing licenses, and bidding contracts; and (4) intelligent $=$ enabling users to create accounts and to personalize the site contents and services [e.g., 6, 7, $8,11]$.

The state economic competitiveness was defined by the state per capita personal income of 2004 [9] and the percent of people 25 years or older who have a bachelor's degree or higher in each state by 2004 [10]. The higher the state per capita personal income and the percent of higher education degrees a state has, the more competitive the state is in economy. We recorded and measured data in the fall of 2005 (see Appendix A) and then conducted a correlation analysis to determine how state economic competitiveness relates with e-government capabilities. Doing so might help determine whether economically more competitive states provide better e-government service or better e-government sites enhance economic competitiveness.

\section{FINDINGS}

Research Question 1 asked, "What are the characteristics of the e-government service sites of the 50 U.S. states and D.C.?" As Table 1 shows, 90\% of the 51 e-government sites presented their homepages within one to two screens to provide a complete picture of what the site is all about; in contrast, $10 \%$ of the sites required visitors to scroll down to the third or even fourth screen for viewing the whole homepage. Regarding the graphic usage, most sites used .jpg pictures (90\%) and gif files (57\%); only a few sites used Flash movies (12\%). These graphic images were of governors' portraits, state attractions, state logos, and welcome signs. Furthermore, over $60 \%$ of the sites provided the following four basic links: contact us, about the state, help center, and privacy/policy; only $49 \%$ offered site map link and $29 \%$, state calendar link.

As Table 1 also indicates, the majority of the state egovernment sites offered the following 12 service links: business/doing business in state (94\%), government agencies (92\%), site search (90\%), online services $(88 \%)$, education/training $(80 \%)$, employment/unemployment $\quad(77 \%), \quad$ travel/ recreation/transportation (77\%), news and events (75\%), citizen/visitor's guide (71\%), family/health/safety (69\%), licenses/permits/ registration (57\%), and law/justice/ legislature (53\%). However, only a few sites also provided their sites in other languages: Spanish (18\%), Chinese (8\%), Korean (8\%), Vietnamese (4\%), and Russian (2\%).

Research Question 2 asked, "What are the capabilities of the state e-government service sites of the 50 U.S. states and D.C.?" Table 2 presents the site capabilities in terms of page loading speed, site capacity, navigation convenience, and overall attractiveness to users. The majority (74\%) of the sites were very efficient or efficient, with $39 \%$ requiring less than one second for page loading and $35 \%$, one to two seconds. In addition, while only four sites $(8 \%)$ belonged to the most advanced intelligent sites enabling users to create accounts and personalize the site contents and services, 39 sites $(76 \%)$ were transactional ones allowing users to do business online such as filing tax documents, renewing licenses, and bidding contracts. The remaining eight sites (16\%) were just interactive ones, on which users could only get or search for information, download forms, and send email. No site was ranked as pure informational site.

Regarding the navigation convenience, most sites were ranked as either very convenient $(27 \%)$ or convenient $(63 \%)$; no site was rated as not convenient. Concerning the sites' overall attractiveness, $77 \%$ of the sites were ranked as either very attractive or attractive; by contrast, $20 \%$ of the sites were rated as less attractive and 4\%, not attractive.

Research Question 3 asked, "How do the state egovernment service capabilities correlate with the state per capita personal income and higher education attainment?" As the correlation analysis in Table 3 shows, while the state per capita personal income and higher education attainment correlated with each other significantly (0.83), they had very weak, insignificant correlations with the capabilities of state e-government sites in terms of loading speed $(0.13$, 0.06), site capacity $(0.01,0.01)$, navigation convenience $(-0.13,-0.10)$, and overall attractiveness $(0.09,-0.05)$. However, a moderate correlation (0.40) existed between navigation convenience and overall attractiveness.

\section{CONCLUSIONS AND RECOMMENDATIONS}

Most of the state e-government homepages were designed with an appropriate page length of one to two screens. This design approach is consistent with the homepage design principle of providing a complete picture of what the site is all about on the 
first screen, or at least by the second, because Web visitors form their first impression of a Web site within just the first few seconds of clicking on [e.g., 1, 12]. However, the findings of the e-government services links on the state homepages have identified some weaknesses for improvement. For example, 10 sites failed to provide education/training links on the homepage, thereby causing inconvenience to educators, students, and other users of the services in those states. Similarly, 12 e-government homepages did not offer links to employment/unemployment services. And 22 homepages failed to provide links to licenses/permits/registration services.

Table 1. Characteristics of State E-Government Service Sites $(\mathrm{N}=51)$

\begin{tabular}{|c|c|c|c|c|c|}
\hline Characteristics & Frequency & Percent & Characteristics & Frequency & Percent \\
\hline \multicolumn{3}{|c|}{ \# of Screens per homepage } & \multicolumn{3}{|l|}{ E-Gov. Service Links } \\
\hline 1 screen & 23 & $45 \%$ & Business/doing business... & 48 & $94 \%$ \\
\hline 2 screens & 23 & $45 \%$ & Government agencies & 47 & $92 \%$ \\
\hline 3 screens & 4 & $8 \%$ & Site search & 46 & $90 \%$ \\
\hline \multirow[t]{2}{*}{4 screens } & 1 & $2 \%$ & Online services & 45 & $88 \%$ \\
\hline & & & Education/training & 41 & $80 \%$ \\
\hline \multicolumn{3}{|c|}{ Graphic File Format } & Employment/unemploy. & 39 & $77 \%$ \\
\hline Jpg & 46 & $90 \%$ & Travel/recrea./transport. & 39 & $77 \%$ \\
\hline Gif & 29 & $57 \%$ & News and events & 38 & $75 \%$ \\
\hline \multirow[t]{2}{*}{ Flash movie } & 6 & $12 \%$ & Citizen/visitor's Guide & 36 & $71 \%$ \\
\hline & & & Family/health/safety & 35 & $69 \%$ \\
\hline \multicolumn{2}{|c|}{ Graphic Illustration } & & Licenses/permits/registra. & 29 & $57 \%$ \\
\hline Governor's pic. & 39 & $77 \%$ & Law/justice/legislature & 27 & $53 \%$ \\
\hline Attractions & 33 & $65 \%$ & State history/culture & 22 & $43 \%$ \\
\hline State logo & 26 & $51 \%$ & Agri./environ./resources & 18 & $35 \%$ \\
\hline \multirow[t]{2}{*}{ Welcome sign } & 20 & $39 \%$ & Public/local assistance & 17 & $33 \%$ \\
\hline & & & Technology & 9 & $18 \%$ \\
\hline \multicolumn{6}{|c|}{ Basic Information Links } \\
\hline Contact us & 37 & $73 \%$ & Site in Other Languages & & \\
\hline About state & 36 & $71 \%$ & Site in Spanish & 9 & $18 \%$ \\
\hline Help center & 34 & $67 \%$ & Site in Chinese & 4 & $8 \%$ \\
\hline Privacy/policy & 33 & $65 \%$ & Site in Korean & 4 & $8 \%$ \\
\hline Site map & 25 & $49 \%$ & Site in Vietnamese & 2 & $4 \%$ \\
\hline State calendar & 15 & $29 \%$ & Site in Russian & 1 & $2 \%$ \\
\hline
\end{tabular}

Second, the majority of the 51 e-government sites had adequate capabilities in page loading speed (74\%), site capacity (84\%), navigation convenience $(90 \%)$, and overall attractiveness $(77 \%)$. All of the sites already evolved away from the pure informational phase into interactive, transactional, or intelligent phases, with $76 \%$ in the transactional phase and $8 \%$ at the intelligent phase. These findings indicate that the state e-government sites on the whole are more advanced than the e-government sites at the city and county levels [e.g., 2, 7]. 
Moreover, the correlation analysis of this study identified very weak, insignificant correlations between the state e-government service capabilities and state per capita personal income and higher education attainment. These findings do not support the result of a previous study at the county level that the per capita personal income correlated significantly with the e-government involvement [11]. This difference appears to explain that the state governments all realized the importance of egovernment and committed proper resources to it even if their state per capita personal income and higher education attainment were lower than those of other states.

Table 2. Capabilities of State E-Government Service Sites $(\mathrm{N}=51)$

\begin{tabular}{lcclcc}
\hline Capabilities & Frequency & Percent & Capabilities & Frequency & Percent \\
\hline Loading Speed & & & Navigation Convenience & & \\
4. $<$ 1 second & 20 & $39 \%$ & 4. Very convenient & 14 & $27 \%$ \\
3. $1-2$ seconds & 18 & $35 \%$ & 3. Convenient & 32 & $63 \%$ \\
2. $3-4$ seconds & 8 & $16 \%$ & 2. Less convenient & 5 & $10 \%$ \\
1. $>4$ seconds & 5 & $10 \%$ & 1. Not convenient & 0 & $0 \%$ \\
& & & & & \\
Site Capacity & 4 & $8 \%$ & Overall Attractiveness & 10 & $20 \%$ \\
4. Intelligent & 39 & $76 \%$ & 3. Attractive & 29 & $57 \%$ \\
3. Transactional & 8 & $16 \%$ & 2. Less attractive & 10 & $20 \%$ \\
2. Interactive & 0 & $0 \%$ & 1. Not attractive & 2 & $4 \%$ \\
1. Informational & & & & & \\
\hline
\end{tabular}

Table 3. Correlation Analysis of State Economic Competitiveness and E-Government Service

\begin{tabular}{|c|c|c|c|c|c|c|}
\hline & $\begin{array}{c}\text { State } \\
\text { Per } \\
\text { Capita } \\
\text { Personal } \\
\text { Income } \\
(\$) \\
\end{array}$ & $\begin{array}{c}\text { State } \\
\text { Higher } \\
\text { Ed. } \\
\text { Degrees } \\
(\%)\end{array}$ & $\begin{array}{c}\text { Site } \\
\text { Loading } \\
\text { Speed } \\
(4 \sim 1)\end{array}$ & $\begin{array}{c}\text { Site } \\
\text { Capacity } \\
(4 \sim 1) \\
\end{array}$ & $\begin{array}{c}\text { Navigation } \\
\text { Convenience } \\
(4 \sim 1) \\
\end{array}$ & $\begin{array}{c}\text { Overall } \\
\text { Attractiveness } \\
(4 \sim 1) \\
\end{array}$ \\
\hline State Per Cap. Per'l Income (\$) & 1 & & & & & \\
\hline State Higher Ed. Degrees (\%) & 0.83 & 1 & & & & \\
\hline Site Loading Speed (4 1) & 0.13 & 0.06 & 1 & & & \\
\hline Site Capacity (4 1) & 0.01 & 0.01 & 0.05 & 1 & & \\
\hline Navigation Convenience (4 1) & -0.13 & -0.10 & 0.20 & 0.19 & 1 & \\
\hline Overall Attractiveness (4 1) & 0.09 & -0.05 & -0.05 & 0.26 & 0.40 & 1 \\
\hline
\end{tabular}

Finally, the findings of this study could help the state e-government administrators compare their sites with the counterparts and identify opportunities for improvement to better serve their constituents. Further study should also be undertaken to investigate whether and how state e-government supports state economic competitiveness. In addition, a follow-up research needs to be conducted in a few years to further examine how the improved capabilities of state e-government correlate with state economic competitiveness.

\section{REFERENCES}

1. Awad, E. M. (2004). Electronic commerce: From vision to fulfillment. Upper Saddle River, NJ: Prentice Hall.

2. Campbell, D. \& Beck, A. C. (2004). Answering allegations: The use of the corporate website for restorative ethical and social disclosure, Business Ethics, 13(2), 100.

3. Cochran, W. G. (1977). Sampling techniques $\left(3^{\text {rd }}\right.$ ed.). New York, NY: John Wiley and Sons. 
4. European Communities. (2005, February 14). Egovernment and competitiveness: identifying the connection. eGovernment News. Retrieved October 2, 2005, from http://europa.eu.int /idabc/jsps/

documents/dsp_showPrinterDocument.jsp?docI $\mathrm{D}=3863 \& \lg =\mathrm{en}$

5. Executive Office of the President of USA. (2004). Expanding e-government: Partnering for a results-oriented government. Retrieved May 1, 2005, from http://www.egov.gov/

6. Koh, C. E. \& Prybutok, V. R. (2003). The three ring model and development of an instrument for measuring dimensions of e-government functions. Journal of Computer Information Systems, 43(3), 34-39.

7. Koh, C.E., Ryan, S., \& Prybutok, V. R. (2005). Creating value through managing knowledge in an e-government to constituency (G2C) environment. Journal of Computer Information Systems, 45(4), 32-41.

8. McCarty, R. V. \& Aronson, J. E. (2000-2001). Activating consumer response: A model for Web site design strategy. Journal of Computer Information Systems, 42(2), 2-7.
9. U.S. Department of Commerce. (2005). State per capita personal income 2004. Bureau of Economic Analysis. Retrieved October 26, 2005, from http://www.bea. gov/bea/newsrel/ spi_highlights.pdf

10. U.S. Census Bureau. (2005). Percent of people 25 years and over who have completed a bachelor's degree or higher by state: 2004. Retrieved October 26, 2005, from http://factfinder.census.gov/ servlet/GRTTable?_bm=y\&-geo_id= 01000US\&-_box_head_nbr=R1402\&ds_name=ACS_2004_EST_G00_\&-format=US30

11. Wilkinson, V. O. \& Cappel, J. J. (2005). Impact of economic prosperity and population on egovernment involvement. Issues in Information Systems, (6), 204-209.

12. Zhao, J. J. (2003). Web Design and Development for E-Business. Upper Saddle River, NJ: Prentice Hall.

13. Zhao, J. J. \& Zhao, S. Y. (2004). Internet Technologies Used by INC. 500 Corporate Web Sites, Issues in Information Systems, (4), 366372.

\section{Appendix A}

State Per Capita Personal Income, Higher Ed. Degrees, and E-Government Capabilities

\begin{tabular}{|c|c|c|c|c|c|c|}
\hline & $\begin{array}{c}\text { State Per } \\
\text { Capita } \\
\text { Personal } \\
\text { Income }(\$)\end{array}$ & $\begin{array}{c}\text { State Higher } \\
\text { Ed. Degrees } \\
(\%)\end{array}$ & $\begin{array}{c}\text { Loading } \\
\text { Speed } \\
(4 \sim 1) \\
\end{array}$ & $\begin{array}{c}\text { Site } \\
\text { Capacity } \\
(4 \sim 1) \\
\end{array}$ & $\begin{array}{c}\text { Navigation } \\
\text { Convenience } \\
(4 \sim 1)\end{array}$ & $\begin{array}{c}\text { Overall } \\
\text { Attractiveness } \\
(4 \sim 1)\end{array}$ \\
\hline 1 Alabama & 27630 & 22.3 & 4 & 3 & 4 & 3 \\
\hline 2 Alaska & 34085 & 25.5 & 3 & 2 & 3 & 3 \\
\hline 3 Arizona & 28609 & 28.0 & 3 & 2 & 3 & 3 \\
\hline 4 Arkansas & 25724 & 18.8 & 3 & 4 & 3 & 3 \\
\hline 5 California & 35172 & 31.7 & 4 & 3 & 4 & 4 \\
\hline 6 Colorado & 36109 & 35.5 & 2 & 3 & 3 & 2 \\
\hline 7 Connecticut & 45506 & 34.5 & 3 & 3 & 3 & 3 \\
\hline 8 Delaware & 35559 & 26.9 & 4 & 3 & 2 & 3 \\
\hline $9 \mathrm{DC}$ & 52101 & 45.7 & 4 & 3 & 3 & 3 \\
\hline 10 Florida & 31460 & 26.0 & 4 & 3 & 4 & 3 \\
\hline 11 Georgia & 30074 & 27.6 & 4 & 3 & 3 & 2 \\
\hline 12 Hawaii & 32606 & 26.6 & 4 & 3 & 4 & 3 \\
\hline 13 Idaho & 26839 & 23.8 & 4 & 3 & 3 & 3 \\
\hline 14 Illinois & 34725 & 27.4 & 3 & 2 & 4 & 3 \\
\hline 15 Indiana & 30070 & 21.1 & 4 & 3 & 3 & 3 \\
\hline 16 Iowa & 30970 & 24.3 & 4 & 2 & 3 & 3 \\
\hline 17 Kansas & 31003 & 30.0 & 4 & 3 & 3 & 3 \\
\hline 18 Kentucky & 27151 & 21.0 & 3 & 3 & 3 & 3 \\
\hline 19 Louisiana & 27219 & 22.4 & 3 & 2 & 3 & 2 \\
\hline 20 Maine & 29973 & 24.2 & 1 & 3 & 2 & 3 \\
\hline
\end{tabular}




\begin{tabular}{|c|c|c|c|c|c|c|}
\hline 21 Maryland & 39629 & 35.2 & 2 & 3 & 2 & 3 \\
\hline 22 Massachusetts & 42102 & 36.7 & 4 & 3 & 3 & 3 \\
\hline 23 Michigan & 32052 & 24.4 & 3 & 3 & 3 & 4 \\
\hline 24 Minnesota & 36173 & 32.5 & 4 & 3 & 3 & 3 \\
\hline 25 Mississippi & 24379 & 20.1 & 2 & 3 & 3 & 4 \\
\hline 26 Missouri & 30516 & 28.1 & 4 & 3 & 4 & 3 \\
\hline 27 Montana & 27666 & 25.5 & 2 & 3 & 4 & 4 \\
\hline 28 Nebraska & 32276 & 24.8 & 4 & 3 & 3 & 3 \\
\hline 29 Nevada & 33783 & 24.5 & 1 & 3 & 3 & 3 \\
\hline 30 New Hampshire & 36676 & 35.4 & 1 & 3 & 3 & 3 \\
\hline 31 New Jersey & 41636 & 34.6 & 4 & 4 & 4 & 4 \\
\hline 32 New Mexico & 26154 & 25.1 & 3 & 3 & 3 & 2 \\
\hline 33 New York & 38333 & 30.6 & 4 & 3 & 3 & 3 \\
\hline 34 North Carolina & 29303 & 23.4 & 4 & 3 & 3 & 3 \\
\hline 35 North Dakota & 29247 & 25.2 & 3 & 3 & 3 & 2 \\
\hline 36 Ohio & 31135 & 24.6 & 4 & 4 & 4 & 4 \\
\hline 37 Oklahoma & 27819 & 22.9 & 3 & 3 & 3 & 2 \\
\hline 38 Oregon & 30584 & 25.9 & 2 & 3 & 3 & 4 \\
\hline 39 Pennsylvania & 33257 & 25.3 & 3 & 3 & 4 & 2 \\
\hline 40 Rhode Island & 34180 & 27.2 & 3 & 3 & 2 & 1 \\
\hline 41 South Carolina & 27153 & 24.9 & 1 & 3 & 3 & 3 \\
\hline 42 South Dakota & 30617 & 25.5 & 4 & 2 & 2 & 1 \\
\hline 43 Tennessee & 29806 & 24.3 & 1 & 3 & 3 & 2 \\
\hline 44 Texas & 30697 & 24.5 & 3 & 3 & 4 & 3 \\
\hline 45 Utah & 26946 & 30.8 & 3 & 3 & 4 & 2 \\
\hline 46 Vermont & 31737 & 34.2 & 3 & 3 & 3 & 2 \\
\hline 47 Virginia & 36175 & 33.1 & 2 & 3 & 3 & 4 \\
\hline 48 Washington & 35017 & 29.9 & 2 & 3 & 3 & 3 \\
\hline 49 West Virginia & 25681 & 15.3 & 3 & 4 & 4 & 4 \\
\hline 50 Wisconsin & 32063 & 25.6 & 2 & 2 & 4 & 4 \\
\hline 51 Wyoming & 34199 & 22.5 & 3 & 2 & 3 & 3 \\
\hline
\end{tabular}

